\title{
Microbiological Stability of Rice Tart Stored at Ambient Temperature after Baking
}

\author{
N'guessan Elise $^{1}$, Cissé Mohamed ${ }^{2}$, Niyonzima Eugène ${ }^{3} \&$ Sindic Marianne $^{1}$ \\ ${ }^{1}$ Université de Liège (Gembloux Agro Bio tech), Belgium \\ ${ }^{2}$ University Peleforo Gon Coulibaly Korhogo, Côte d'Ivoire \\ ${ }^{3}$ Université of Rwanda, Rwanda
}

Received: February 17, 2017

Accepted: April 21, $2017 \quad$ Online Published: August 21, 2017

doi:10.5539/jfr.v6n5p41

URL: https://doi.org/10.5539/jfr.v6n5p41

\begin{abstract}
Very popular in Belgium, rice tart is a hot pastry sold in bakeries. It is then consumed at home, for dessert or snack. This study is conducted to investigate the microbiological stability of this foodstuff, from the end of baking to end user by consumers. In this purpose, 108 rice tart samples were collected from each of seven bakeries in five Belgium provinces. Physico-chimical analysis in addition to microbiological analysis were carried out in accordance with the European Regulation EC 2073/2005 and with references methods, to enumerate the total microorganisms count, Staphylococcus aureus, Bacillus cereus as well as Enterobacteria, susceptible likely to contaminate the tarts during the production or after baking. Even when the results meet the microbiological safety standards immediately after baking in all bakeries implicated, a significant $(p<0,05)$ increase of mesophilic aerobic bacteria (ranging from $<1$ to $7 \mathrm{log} \mathrm{cfu} / \mathrm{g}$ ) and $B$. cereus $(>3,7 \mathrm{log} \mathrm{cfu} / \mathrm{g}$ ) was observed during the storage at nonrefrigerated temperature $\left(28\right.$ to $\left.30^{\circ} \mathrm{C}\right)$. A post-baking recontamination and other parameters like an insufficient baking time or a non uniform distribution of the oven heat could explain the observed bacteria growth. The present study shows that most rice tarts investigated are microbiologically safe. However, the possible increase of bacteria load in this foodstuff attributable to the favorable $\mathrm{a}_{\mathrm{w}}, \mathrm{pH}$ and temperature conditions, highlight the importance of applying good hygienic practices and compliance with storage conditions after baking to ensure consumer safety.
\end{abstract}

Keywords: bacteria, bakery, increase, microbial load, rice tart, safety

\section{Introduction}

Bakery products are part of the processed food category. They include cake, pastries, biscuits, bread, breakfast cereals, and other products. They hold among foods products, a significant market share. The bakery market in Canada for example, registered total value sales of $\mathrm{C} \$ 8.6$ billion and total volume sales of 1.2 million tonnes in 2011 (Agriculture and Agri-Food Canada, 2013). Today, their production has evolved from a primitive, cottage industry into a modern manufacturing industry, promoting the increase in sale volume within the past decades (Kohn, 2000; Smith, Daifas, El-Khoury, Koukoutsis and El-Khoury 2004).

Bakery products could constitute the potential vehicles of a wide range of food poisoning microorganisms to humans because of their chemical composition that favors the proliferation of these pathogens. In fact, bakery products are an important source of carbohydrates fats, proteins, minerals and vitamins (Seiler, 1978, Saranraj and Geetha, 2012). For example, bread and biscuits contain around 7, 5 per cent to 7,8 per cent protein respectively. According to Osimani et al., 2016, the factors that can contribute to the production of good bakery products quality are the raw materials quality, the production technology and the plant hygiene.

The high diversity of pastries in water activity and in $\mathrm{pH}$ provides a variety of habitats for the bacteria growth (Novac, Sapers and Juneja 2002). Sharifzadeh, Hajsharifi-Shahreza and Ghasemi-Dehkordi $l$ (2016) enumerated several microorganisms including Coliform, Staphylococci and yeast from cream-filled pastries made in Iran. Similarly, Voysey and Legan (2014) identified molds and yeasts as the key spoilage microorganisms in these bakery products. Microorganisms development in pastries can either speed up the organoleptic quality degradation or cause foodborne diseases. Thus, in July 2012, in the city of Lujan, Argentina, five individuals were affected after eating a handmade Viennese-style pastry at a family gathering. All of them presented with fever, joint pain, chills and non-bloody diarrhea containing mucus. Samples taken from the pastry ingredients 
were analyzed microbiologically. The results emphasize a contamination by Shigella sonnei, during the manipulation in the bakery (Della et al., 2015). Furthermore, Kotzekidou, (2013) emphasized a contamination and poor microbiological quality of frozen pastries. Bacteria like Bacillus cereus, Salmonella spp., presumptive Escherichia coli O157, Listeria monocytogenes and Staphylococcus aureus were concerned.

Rice tart is consumed at home, often sprinkled with icing sugar, for dessert or snack. According to the flow diagram, this tart specialty is made from several ingredients such as rice, eggs and cow raw milk. These ingredients could be potential sources of microbiological contamination. Several pathogens such as Staphylococcus aureus, Bacillus cereus and Listeria monocytogenès may be taken into consideration as potential hazard associated with rice tarts (AFSCA, 2015).

Rice tart is made in a variety of formats and the baking time and temperature are in each case, sufficient to destroy any vegetative microbes which are present prior to baking. However, a number of Bacillus spp spores are able to withstand the cooking temperature during the baking process and may grow to levels of public health concern with toxin production, if packaging and storage conditions are conductive to their growth (Bryan Guzewich and Todd l., 1997, Leuschner, O'callaghan, and Arendt 1998, Rosenquist, Smidt, Anderson, Jensen and Wilcks 2005; Asadi, Maram and Kooshk 2015, André, Vallaeys, and Planchon, 2016). In respect to the organoleptic characteristics of rice tart namely the taste, appearance and smoothness traditional friendly bakers use to keep rice tarts at room temperature during 15 to 24 hours (time to sale), instead of storing them in refrigerators after production. Given that rice is part of the foodstuffs susceptible to promote the Bacillus cereus emetic development, the storage of tarts at room temperature could be at the origin of food safety issues for consumers.

In fact, Among the food matrices associated with B. cereus emetic poisoning, rice is certainly one of the most important source of contamination (Altayar and Sutherland, 2006; Ankolekar and Labbe, 2009; Shiota et al., 2010; Martinelli et al., 2013; Organji, Abulreesh, Elbanna, Osman and, Khider2015). Not only rice is easily contaminated with soil-borne spores of B. cereus (Sarrias Valero, Salmeron 2002; Kim et al., 2014), but the way rice is prepared for human consumption can promote its survival, outgrowth and toxin production during vegetative growth (Finlay Logan, Sutherland 2002). According to Jaaskelainen, (2003), rice-containing pastries accumulated high contents of cereulide, a Bacillus emetic toxin $(0,3$ to $5,5 \mu \mathrm{g} / \mathrm{g}$ [wet weight]), when stored at non-refrigeration temperatures $\left(21\right.$ to $23^{\circ} \mathrm{C}$ ). Cereulide is a pH and heat stable cyclic peptide toxin. (Agata, Ohta, Mori and Isobe., 1995, Rajkovic et al., 2008). This toxin is responsible of the emetic food poisoning syndrome, including fatal cases of food intoxications. Moreover, the increase in the number of fatal or very severe emetic outbreaks since 2000 is worthy of note (Dierick et al., 2005; Posfay-Barbe, Schrenzel, Frey, Studer, Korff and Belli 2008; Shiota et al., 2010). The cause of death or illness was attributed to liver failure, but also to acute encephalopathy and presumably acute cardiac insufficiency (Naranjo et al., 2011; Carlin and Nguyen-The, 2013).

The aim of this work is to study the microbiological stability of rice tart after baking. For this purpose, the development of microorganisms like total count bacteria, Bacillus cereus, Staphylococcus aureus, as well as Enterobacteriacea were monitored at non-refrigerated temperature $\left(30^{\circ} \mathrm{C}\right)$.

\section{Materials and Methods}

\subsection{Rice Tarts Sampling}

108 medium size rice tart samples were collected from seven bakeries in five provinces of Belgium from May to July 2014. The total number of the collected samples in different bakeries is described in Table 1. Tart samples were conditioned in the sale packaging and held at $4^{\circ} \mathrm{C}$ in a cooling box, then transported to the laboratory for analysis within approximately $40 \mathrm{~min}$. Samples were stored at $4^{\circ} \mathrm{C}$ until analysis. Cooking schedule applied at all producers are summarized in table 2 . Rice tarts were then stored at nonrefrigerated temperature $\left(30^{\circ} \mathrm{C}\right)$ throughout the analyses at $\mathrm{t} 0, \mathrm{t} 24, \mathrm{t} 48$ hours.

Table 1. Sampling protocol for Rice tarts

\begin{tabular}{lcc}
\hline Provinces & Bakeries & Sample numbers \\
\hline Liège & $\mathrm{A}$ & 18 \\
Luxembourg & $\mathrm{B}$ & 18 \\
Namur & $\mathrm{C}$ & 18 \\
Liège & $\mathrm{D}$ & 18 \\
Liège & $\mathrm{E}$ & 12 \\
Brabant Flamand & $\mathrm{F}$ & 12 \\
Hainaut & $\mathrm{G}$ & 12 \\
\hline
\end{tabular}


Table 2. Rice tart baking schedule and shelf life

\begin{tabular}{lccccccc}
\hline Parameters/Bakeries & A & B & C & D & E & F & G \\
\hline Baking temperature $\left({ }^{\circ} \mathrm{C}\right)$ & 260 & 230 & 240 & 210 & 270 & 190 & 260 \\
Baking time (min) & 25 & 30 & 20 & 40 & 30 & 45 & 45 \\
Cooling temperature $\left({ }^{\circ} \mathrm{C}\right)$ & 20 & 20 & 20 & 20 & 20 & $18^{\circ} \mathrm{C}$ & 20 \\
Estimated Shelf life by producers & 48 & 12 & 48 & 48 & 72 & 48 & 48 \\
\hline
\end{tabular}

\subsection{Physico-chemical Analyses}

Microbiological and physico-chimical analysis were carried out to enumerate the total mesophilic bacteria, Staphylococcus aureus, Bacillus cereus as well as Enterobacteria which could have contaminated the tarts during the production or after baking, either through the ingredients, or by product handling. The water activity and $\mathrm{pH}$ of rice tarts were also determined in order to measure the impact of these parameters on bacteria development.

The $\mathrm{pH}$ meter wtwpH340 (Mettler Toledo, Belgium) was used for the $\mathrm{pH}$ measurement. The tart was divided into four sections. The measurement was performed by inserting the probe of the $\mathrm{pH}$ meter in each part of the rice tart. The $\mathrm{pH}$ of the tart was calculated as the mean of the four measurements. The $\mathrm{pH}$ meter was calibrated before each use.

The water activity $\left(\mathrm{a}_{\mathrm{w}}\right)$ measurement was established in a AquaLab (models series 3 and 3TE, USA) at $23 \pm 2^{\circ} \mathrm{C}$. The mirror dew point technique was used. The measurement consisted in introduction of a cup containing $1 / 3$ of the tart volume, in the AquaLab. This tart portion was taken from inside of the tart, without the crust. The measuring device was calibrated before each measurement.

\subsection{Microbiological Analysis}

Microbiological analyses were carried out by an accredited environmental, toxicology and food control laboratory in accordance with the EC 2073/2005 regulation. Overall, 108 rice tarts samples were analyzed in accordance with the European Regulation EC 2073/2005. Reference methods were used for the enumeration of total bacteria count (ISO 4833-2); Staphylococcus aureus (ISO 6888-3); Bacillus cereus (ISO ISO 7932: 2004) and Enterobacteriaceae (ISO 21528-2) (ISO 2003; 2004; 2013). Microbiological analyses on rice tarts were carried out at three times namely immediately post baking, after 24 hours and after 48 hours. The microbiological stability of rice tarts involved in this study was assessed using criteria in the EC 2073/2005 recommendations (Table 3).

Table 3. Microbiological criteria as recommended by the Commission Regulation EC 2073/2005 on microbiological criteria for milk based dessert (dessert, pastries)

\begin{tabular}{clccccccc}
\hline Sectors & Microorganisms & $\mathrm{n}$ & $\mathrm{c}$ & Satisfactory $\left(\mathrm{m}^{\mathrm{a}}\right)$ & Acceptable $\left(\mathrm{M}^{\mathrm{b}}\right)$ & unsatisfactory & Unit & $\begin{array}{c}\text { European } \\
\text { commission 2005. }\end{array}$ \\
\hline Distribution & Total bacteria count & 5 & 2 & $\leq 100000$ & $\leq 1000000$ & $>1000000$ & $\mathrm{ufc} / \mathrm{g}$ & Guide value \\
Distribution & Enterobacteriaceae & 5 & 2 & $\leq 500$ & 5000 & $>5000$ & ufc/g & Guide value \\
Distribution & B. cereus & 5 & 2 & $\leq 1000$ & 10000 & $>10000$ & ufc/g & Guide value \\
Distribution & Staphylococcus & 5 & 2 & $\leq 100$ & 1000 & $>1000$ & ufc/g & Guide value \\
\hline
\end{tabular}

${ }^{a}$ In a three-class sampling plan, the " $m$ " limit is used to distinguish acceptable quality units (under good manufacturing practices) from those of poor quality.

${ }^{\mathrm{b}}$ The numerical value of "M" represents unacceptable concentrations of microorganisms. Exceeding the " $\mathbf{m}$ " level requires corrective action, i.e. revision of the HACCP plan. Exceeding the "M" value requires a recall of the product from the market.

The number of sampling units is represented by $n$

The maximum allowable number of sample(s) that yielded unsatisfactory test results is represented by "c".

\subsection{Statistical Analysis}

Experimental data were compiled in Microsoft Excel 2010 software (Manufacturer, country) for descriptive and statistical analyses and were then subjected to ANOVA analysis using Statistica 7(Manufacturer, country)with Fisher LSD. The overall least significant differences $(\mathrm{p}<0.05)$ were calculated and used to detect significant differences among analyses. Each experiment was performed in triplicate.

\section{Results and Discussion}

In order to investigate the microbiological stability of rice tarts during the storage for sale, 108 tarts samples were collected through different Belgian bakeries for physico-chemical characteristic and microbiological 
analyses.

\subsection{Physicochemical Characteristic}

Averages of $\mathrm{pH}$ and water activity results of rice tarts analyzed are summarized in the table 4. $\mathrm{pH}$ values ranged from 5.9 to 6.5 while the water activity ranged from 0.970 to $0.99,24$ and 48 hours after baking. Statistically, no significant differences $(p<0,05)$ in $a_{w}$ were observed during the rice tarts storage at non refrigeration temperature, in the seven bakeries. Overall, no increasing in $\mathrm{a}_{\mathrm{w}}$ was registered. By contrast, the results showed a variability in $\mathrm{pH}$ values 24 and 48 hours after the baking (table 4). According to a study ranking bakery products on the basis of their $\mathrm{a}_{\mathrm{w}}$ the rice tart used in this study could be considered as high moisture content product (Novak et al.,2002). Furthermore, a growth simulation of pathogenic microorganisms in rice tart, conducted by the FASFC (Federal Agency for the Safety of the Food Chain) in 2015, showed that with a pH of 6.5 and $\mathrm{a}_{\mathrm{w}}$ value of 0.993 , rice tarts are more likely to promote pathogenic bacteria growth at $24^{\circ} \mathrm{C}$ and $26^{\circ} \mathrm{C}$. In the light of the above, the rice tarts analyzed in our study should be potentially susceptible to promote spoilage by bacteria, yeast and molds under extreme ambient temperature (Smith et al., 2010).

Table 4. Measurement of rice tart $\mathrm{pH}$ and water activity. Values are mean ( \pm standard deviation) of triplacate $\mathrm{pH}$ and $\mathrm{a}_{\mathrm{w}}$ measurements. In the same column, same bakery and same parameter; different superscript letters indicate a significant difference $(\mathrm{p}<0.05)$

\begin{tabular}{cccc}
\hline Bakeries & Times $(\mathrm{h})$ & $\mathrm{pH}$ & $\mathrm{a}_{\mathrm{w}}$ \\
\hline & $\mathrm{t} 0$ & $6.42^{\mathrm{f}} \pm 0.07$ & $0.99^{\mathrm{a}} \pm 0.01$ \\
$\mathrm{~A}$ & $\mathrm{t} 24$ & $6.49^{\mathrm{f}} \pm 0.03$ & $0.99^{\mathrm{a}} \pm 0.06$ \\
& $\mathrm{t} 48$ & $6.22^{\mathrm{de}} \pm 0.16$ & $0.99^{\mathrm{a}} \pm 0,00$ \\
\hline \multirow{3}{*}{$\mathrm{B}$} & $\mathrm{t} 0$ & $5.99^{\mathrm{ab}} \pm 0.11$ & $0.99^{\mathrm{a}} \pm 0.03$ \\
& $\mathrm{t} 24$ & $6 \mathrm{a}^{\mathrm{bc}} \pm 0.09$ & $0.98^{\mathrm{a}} \pm 0.02$ \\
& $\mathrm{t} 48$ & $6.16^{\mathrm{cd}} \pm 0.06$ & $0.98^{\mathrm{a}} \pm 0.05$ \\
\hline & $\mathrm{t} 0$ & $6.12^{\mathrm{bcd}} \pm 0.03$ & $0.98^{\mathrm{a}} \pm 0.00$ \\
$\mathrm{C}$ & $\mathrm{t} 24$ & $6.01^{\mathrm{abc}} \pm 0.04$ & $0.98^{\mathrm{a}} \pm 0.05$ \\
& $\mathrm{t} 48$ & $6.07^{\mathrm{abcd}} \pm 0.02$ & $0.98^{\mathrm{a}} \pm 0.02$ \\
\hline & $\mathrm{t} 0$ & $6.1^{\mathrm{abcd}} \pm 0.05$ & $0.98^{\mathrm{a}} \pm 0.1$ \\
$\mathrm{D}$ & $\mathrm{t} 24$ & $5.94^{\mathrm{a}} \pm 0.05$ & $0.98^{\mathrm{a}} \pm 0.07$ \\
& $\mathrm{t} 48$ & $6.08^{\mathrm{abcd}} \pm 0.1$ & $0.98^{\mathrm{a}} \pm 0.00$ \\
\hline \multirow{3}{*}{$\mathrm{E}$} & $\mathrm{t} 0$ & $6.39^{\mathrm{f}} \pm 0.14$ & $0.98^{\mathrm{a}} \pm 0.01$ \\
& $\mathrm{t} 24$ & $6.09^{\mathrm{abcd}} \pm 0.05$ & $0.98^{\mathrm{a}} \pm 0.06$ \\
& $\mathrm{t} 48$ & $6.09^{\mathrm{abcd}} \pm 0.05$ & $0.98^{\mathrm{a}} \pm 0.08$ \\
\hline & $\mathrm{t} 0$ & $6.1^{\mathrm{abcd}} \pm 0.08$ & $0.98^{\mathrm{a}} \pm 0.09$ \\
$\mathrm{~F}$ & $\mathrm{t} 24$ & $6.03^{\mathrm{abc}} \pm 0.1$ & $0.97^{\mathrm{a}} \pm 0.01$ \\
& $\mathrm{t} 48$ & $6.03^{\mathrm{abc}} \pm 0.1$ & $0.97^{\mathrm{a}} \pm 0.04$ \\
\hline & $\mathrm{t} 0$ & $6.06^{\mathrm{abcd}} \pm 0.04$ & $0.98^{\mathrm{a}} \pm 0.00$ \\
$\mathrm{G}$ & $\mathrm{t} 24$ & $6.21^{\mathrm{de}} \pm 0.04$ & $0.98^{\mathrm{a}} \pm 0.01$ \\
& $\mathrm{t} 48$ & $6.36^{\mathrm{ef}} \pm 0.04$ & $0.98^{\mathrm{a}} \pm 0.03$ \\
\hline
\end{tabular}

\subsection{Microbiological Quality of Rice Tart}

Tables 5 present the results of microbiological analyses performed on rice tarts, in seven different bakeries. The analyses were done at $\mathrm{t} 0, \mathrm{t} 24$ and $\mathrm{t} 48$ hours after baking. According to the results, there was lots of variability of mesophilic aerobic bacteria number between the analysis times, within the same bakery. A significant $(p<0,05)$ increasing of these bacteria counts was observed at $\mathrm{t} 24$ and $\mathrm{t} 48$, in the seven bakeries concerned. No significant differences in the evolution in Enterobacteria and $S$. aureus concentration have been found at $\mathrm{t} 24$ and $\mathrm{t} 48$, for all bakeries $(\mathrm{p}<0,05)$. Likewise, no significant variability was observed in the number of $B$. cereus and $B$. cereus spores between $\mathrm{t} 0$ and $\mathrm{t} 24$ or $\mathrm{t} 24$ and $\mathrm{t} 48$ for the bakeries $\mathrm{D}, \mathrm{E}, \mathrm{F}$ and G. But, an increasing in B. cereus concentration was observed at $\mathrm{t} 24$ and $\mathrm{t} 48$ for the other three bakeries $(\mathrm{A}, \mathrm{B}, \mathrm{C})$.

Even if they are sometimes, an increasing in bacteria concentration during the rice tarts storage, these foodstuffs were found to be within microbiologically satisfactory limits, immediately $(\mathrm{t} 0)$ after baking, for Enterobacteria, total bacteria counts, S. aureus, B. cereus and spore of B. cereus. The compliance regarding microbiological criteria of rice tarts, immediately after baking indicates that there is a very low likelihood of any vegetative bacteria contamination surviving the baking process. The significant increasing of bacteria count (mesophilic aerobic bacteria and $B$. cereus) during the storage $(\mathrm{t} 24, \mathrm{t} 48)$ at non-refrigeration temperature $\left(30^{\circ} \mathrm{C}\right)$ could be linked to a post-baking recontamination combined with the storage temperature, as the baking temperature is normally enough to eliminate previous contamination. Several other parameters could have influenced the 
quality of the rice tarts during the baking and explain bacteria growth. Among them, an insufficient baking time or a non uniform distribution of the oven heat; in these circumstances, the mean core temperature of the rice tarts could be not enough heated, allowing some heat resistant B. cereus spores survival and germination during the storage at ambient temperature (Lainez, Vergara, María and Bárcenas 2008; Sani, Taip, Kamal and Aziz 2014). The favorable terms created by the $\mathrm{a}_{\mathrm{w}}$ and $\mathrm{pH}$ close to neutral (tables 3 ) of rice tarts 24 and 48 hours after baking, could probably have promoted the heat resistant B. cereus spore germination and the growth of bacteria commonly associated with these products (Trujillo, Yeow and Pham 2003; Lebert, Baucour, Lebert and Daudin 2005; Ureta, Olivera and Salvadori 2016; Reid et al., 2017). Cereulide is formed when cereulide-producing $B$. cereus strains were present at $>$ or $=10^{6} \mathrm{cfu} / \mathrm{g}$ in product with water activity values of $>0,953$ and $\mathrm{pH}$ of $>5,6$. Moreover, rice-containing pastries could accumulated high contents of cereulide $(0,3$ to $5,5 \mathrm{microg} / \mathrm{g}$ [wet weight]) when stored at nonrefrigerated temperature (Jääskeläinen et al., 2003). In the extreme temperature condition used in this study, B. cereus developed to a concentration $>3,5 \log \mathrm{cfu} / \mathrm{g}$. However, it is important to note that the cereulide producing B. cereus are rare, around 1\% (Altayar and Sutherland, 2006). Furthermore, a study conducted by the Federal Agency for the Safety of the Food Chain (FASFC) in 2016, including pilot studies, a consumer survey and simulation tests, related to rice tarts showed that The risk related to food safety associated with the consumption of rice tarts contaminated with Bacillus cereus remains low at $22^{\circ} \mathrm{C}$ for 12 hours of storage.

The rice tarts sampled from the bakery F remain acceptable for $S$. aureus, with a microbial load of $2,5 \log \mathrm{cfu} / \mathrm{g}$ at t0 (Table 5). The significance of this microorganism in foods has been reported through different studies (Hennekinne, Marie-Laure De Buyser and Dragacci 2012; Guitiérrez et al., 2012). In the current study, the presence of this bacterium in the rice tart could be link to a mishandling after baking or during the storage. Indeed, this pathogen can reside on the skin and mucosal surfaces of humans and animals, besides being an exceptionally well adapted opportunistic, able to survive under different conditions (Soares et al., 2011; Brown Cornforth, and Mideo 2012; Batista et al., 2016).

The incidence of foods products post-baking contamination related to the direct contact has been previously highlighted (Pérez-Rodríguez et al., 2007; Kotzekidou, 2013; Voysey and Legan, 2014). In the same vein, a study conducted on the evaluation of microbial contamination of pastries in confectioneries in Iran, revealed an incidences of S. aureus with 48,68\% (Sharifzadeh et al., 2016). The sources of the contamination were related to handlers and nonconformity of the hygiene standards.

Table 5. Bacteria counts of rice tarts from seven bakeries in Belgium. Values are mean( \pm standard deviation) of triplicate bacterial loads (in log cfu/g) measurements. In the same column, same bakery and same parameter; different superscript letters indicate a significant difference $(\mathrm{p}<0.05)$

\begin{tabular}{|c|c|c|c|c|c|c|}
\hline \multirow[b]{2}{*}{ Bakeries } & \multirow[b]{2}{*}{ Times $(\mathrm{h})$} & \multicolumn{5}{|l|}{ Bacteria } \\
\hline & & Mesophilic aerobic bacteria & Enterobacteria & S. aureus & B. cereus & Spore B. cereus \\
\hline \multirow{3}{*}{ A } & t0 & $1.20^{\mathrm{a}} \pm 0,35$ & $1^{\mathrm{a}} \pm 0.00$ & $1.2^{\mathrm{a}} \pm 0.35$ & $1^{\mathrm{a}} \pm 0.00$ & $1^{\mathrm{a}} \pm 0.00$ \\
\hline & $\mathrm{t} 24$ & $7.60^{\mathrm{hi}} \pm 0,08$ & $1^{\mathrm{a}} \pm 0.00$ & $1^{\mathrm{a}} \pm 0.00$ & $3.63^{\mathrm{b}} \pm 0.07$ & $1.67^{b} \pm 0.66$ \\
\hline & $\mathrm{t} 48$ & $8.13^{\mathrm{i}} \pm 0,08$ & $1^{\mathrm{a}} \pm 0.00$ & $1^{\mathrm{a}} \pm 0.00$ & $3.72^{\mathrm{b}} \pm 0.07$ & $3.65^{\mathrm{c}} \pm 0.06$ \\
\hline \multirow{3}{*}{ B } & t0 & $1.20^{\mathrm{a}} \pm 0,35$ & $1^{\mathrm{a}} \pm 0.00$ & $1^{\mathrm{a}} \pm 0.00$ & $1^{\mathrm{a}} \pm 0.00$ & $1^{\mathrm{a}} \pm 0.00$ \\
\hline & $\mathrm{t} 24$ & $4.40^{\mathrm{d}} \pm 1,04$ & $1.2^{\mathrm{a}} \pm 0.35$ & $1^{\mathrm{a}} \pm 0.00$ & $1^{\mathrm{a}} \pm 0.00$ & $1^{\mathrm{a}} \pm 0.00$ \\
\hline & $\mathrm{t} 48$ & $7.75^{\mathrm{hi}} \pm 0,06$ & $3.71^{\mathrm{b}} \pm 0.10$ & $1^{\mathrm{a} \pm 0.00}$ & $1^{\mathrm{a} \pm 0.00}$ & $1^{\mathrm{a}} \pm 0.00$ \\
\hline \multirow{3}{*}{$\mathrm{C}$} & t0 & $1.20^{\mathrm{a}} \pm 0,35$ & $1^{\mathrm{a}} \pm 0.00$ & $1^{\mathrm{a}} \pm 0.00$ & $1^{\mathrm{a}} \pm 0.00$ & $1^{\mathrm{a}} \pm 0.00$ \\
\hline & $\mathrm{t} 24$ & $5.24^{\mathrm{ef}} \pm 0,68$ & $1^{\mathrm{a}} \pm 0.00$ & $1^{\mathrm{a}} \pm 0.00$ & $3,54^{\mathrm{b}} \pm 0.17$ & $1^{\mathrm{a}} \pm 0.00$ \\
\hline & $\mathrm{t} 48$ & $7.25^{\mathrm{h}} \pm 0,05$ & $1.2^{\mathrm{a}} \pm 0.35$ & $1^{\mathrm{a}} \pm 0.00$ & $3,59^{\mathrm{b}} \pm 0.09$ & $1^{\mathrm{a}} \pm 0.00$ \\
\hline \multirow{3}{*}{$\mathrm{D}$} & to & $1.20^{\mathrm{a}} \pm 0,35$ & $1^{\mathrm{a}} \pm 0.00$ & $1^{\mathrm{a}} \pm 0.00$ & $1^{\mathrm{a}} \pm 0.00$ & $1^{\mathrm{a}} \pm 0.00$ \\
\hline & $\mathrm{t} 24$ & $3.30^{\mathrm{c}} \pm 0,75$ & $1^{\mathrm{a}} \pm 0.00$ & $1^{\mathrm{a}} \pm 0.00$ & $1^{\mathrm{a}} \pm 0.00$ & $1^{\mathrm{a}} \pm 0.00$ \\
\hline & $\mathrm{t} 48$ & $6.39^{\mathrm{g}} \pm 0,24$ & $1^{\mathrm{a}} \pm 0.00$ & $1^{\mathrm{a}} \pm 0.00$ & $1^{\mathrm{a}} \pm 0.00$ & $1^{\mathrm{a}} \pm 0.00$ \\
\hline \multirow{3}{*}{$\mathrm{E}$} & to & $1.40^{\mathrm{a}} \pm 0,35$ & $1^{a} \pm 0.00$ & $1^{\mathrm{a}} \pm 0.00$ & $1.2^{\mathrm{a}} \pm 0.35$ & $1^{\mathrm{a}} \pm 0.00$ \\
\hline & $\mathrm{t} 24$ & $3.32^{\mathrm{c}} \pm 0,61$ & $1^{\mathrm{a}} \pm 0.00$ & $1^{\mathrm{a}} \pm 0.00$ & $1^{\mathrm{a}} \pm 0.00$ & $1^{\mathrm{a}} \pm 0.00$ \\
\hline & $\mathrm{t} 48$ & $5.61^{\mathrm{f}} \pm 0,14$ & $1^{\mathrm{a}} \pm 0.00$ & $1 \mathrm{a} \pm 0.00$ & $1^{\mathrm{a}} \pm 0.00$ & $1^{\mathrm{a}} \pm 0.00$ \\
\hline \multirow{3}{*}{$\mathrm{F}$} & to & $1.40^{\mathrm{a}} \pm 0,35$ & $1^{\mathrm{a}} \pm 0.00$ & $1.69^{a} \pm 0.73$ & $1^{\mathrm{a}} \pm 0.00$ & $1^{\mathrm{a}} \pm 0.00$ \\
\hline & $\mathrm{t} 24$ & $4.85^{\mathrm{de}} \pm 0,09$ & $1^{\mathrm{a}} \pm 0.00$ & $1^{\mathrm{a}} \pm 0.00$ & $1^{\mathrm{a}} \pm 0.00$ & $1^{\mathrm{a}} \pm 0.00$ \\
\hline & $\mathrm{t} 48$ & $7.77^{\mathrm{hi}} \pm 0,25$ & $1^{\mathrm{a}} \pm 0.00$ & $1^{\mathrm{a}} \pm 0.00$ & $1^{\mathrm{a}} \pm 0.00$ & $1^{\mathrm{a}} \pm 0.00$ \\
\hline \multirow{3}{*}{ G } & to & $1^{a} \pm 0,00$ & $1^{\mathrm{a}} \pm 0.00$ & $1^{\mathrm{a} \pm 0.00}$ & $1^{\mathrm{a} \pm 0.00}$ & $1^{\mathrm{a}} \pm 0.00$ \\
\hline & $\mathrm{t} 24$ & $2.52^{\mathrm{b}} \pm 0,08$ & $1^{\mathrm{a}} \pm 0.00$ & $1^{\mathrm{a}} \pm 0.00$ & $1^{\mathrm{a} \pm 0.00}$ & $1^{\mathrm{a}} \pm 0.00$ \\
\hline & $\mathrm{t} 48$ & $5.45^{\mathrm{ef}} \pm 0,39$ & $1^{\mathrm{a}} \pm 0.00$ & $1.8^{\mathrm{a}} \pm 1.39$ & $1.57^{-} \pm 0.98$ & $1^{\mathrm{a}} \pm 0.00$ \\
\hline
\end{tabular}

\section{Conclusion}

The rice tarts were found to be within microbiologically satisfactory limits defined by the Regulation EC 
2073/2005, immediately after baking for all bacteria tested, regardless the applied cooking schedule. An increase in B. cereus and B. cereus spores counts were observed 24 hours after baking, at non-refrigeration temperature ( 28 to $30^{\circ} \mathrm{C}$ ). Although not enough to constitute a potential major hazard to consumers health in this study, $B$. cereus and its toxins can present a hazard in foods and can affect the health of the consumer. Especially, when favorable terms are created by the $\mathrm{a}_{\mathrm{w}}$ and $\mathrm{pH}$ as it is the case in our study. Therefore, adequate hygienic practices are needed, mainly after baking to avoid the post-contamination of rice tarts and for the consumer protection.

\section{Acknowledgements}

This work was supported by producers of rice tarts in seven provinces of Belgium. The producers had no role in study design, data collection and analysis, decision to publish, or preparation of the manuscript. We also thank the personnel of the Laboratory of Agro-food Quality and Safety of the University of Liege - Gembloux Agro-Bio Tech, for many discussions and helpful comments.

\section{References}

Agata, N., Ohta, M., Mori, M., \& Isobe, M. (1995). A novel dodecadepsipeptide, cereulide, is an emetic toxin of Bacillus cereus. FEMS Microbiology Letters, 129(1), 17-20. https://doi.org/10.1016/0378-1097(95)00119-P

Agriculture and Agri-Food Canada. (2013). Consumer Trends - Bakery Products in Canada. ISSN 1920-6593 Market indicator report. AAFC $\mathrm{N}^{\circ} 11942 \mathrm{E}$.

Seiler, D. A. L. (1978). The microbiology of cake and its ingredients. Food Trade Review. 48(6), 339-344.

Altayar, M., \& Sutherland, A. D. (2006). Bacillus cereus is common in the environment but emetic toxin producing isolates are rare. Journal of Appied. Microbiology, 100(1), 7-14. https://doi.org/10.1111/j.1365-2672.2005.02764.x

André, S., Vallaeys, T., \& Planchon, S. (2016). Spore-forming bacteria responsible for food spoilage. Research in microbiology. http://dx.doi.org/10.1016/j.resmic.2016.10.003

Ankolekar, C., \& Labbe', R. G. (2010). Physical characteristics of spores of food-associated isolates of the bacillus cereus group.. Applied. Environment. Microbiology, 76(3), 982-984. https://doi.org/10.1128/AEM.02116-09

Asadi, S., Maram, Z. R., \& Kooshk, F. (2015). Evaluation of microbial contamination of pastry cream in Arak city of Iran. Journal of Food Safety and Hygiene, 1(1), 26-29.

Baptista, I., Sílvia, M., Rocha, S. M., Cunha, A., Saraiva, J. A., \& Almeida, A. (2016). Inactivation of Staphylococcus aureus by high pressure processing: An overview. Innovative. Food Science and Emerging Technologies, 36, 128-149. https://doi.org/10.1016/j.ifset.2016.06.008

Brown, S. P., Cornforth, D. M., \& Mideo, N. (2012). Evolution of virulence in opportunistic pathogens: Generalism, plasticity, and control. Trends in Microbiology, 20(7), 336-342. https://doi.org/10.1016/j.tim.2012.04.005

Bryan, F. F., Guzewich, J. J., \& Todd, E. C. D. (1997). Surveillance of foodborne disease. III. Summary and presentation of data on vehicles and contributory factors; their value and limitations, Journal of Food Protection, 60, 701-714. https://doi.org/10.4315/0362-028X-60.6.701

Carlin, F., \& Nguyen-The, C. (2013). Pathogen update: Bacillus species. Advance in microbial safety, 70-96. https://doi.org/10.1533/9780857098740.2.70

Christiansson, A., Bertilsson, J., \& Svensson, B. (1999). Bacillus cereus spores in raw milk: factors affecting the contamination of milk during the grazing period. Journal of Dairy Science, 82(2), 305-14. https://doi.org/10.3168/jds.S0022-0302(99)75237-9

Cui, Y., Liu, Y., Liu, X., Xia, X., Ding, S., \& Zhu, K. (2016). Evaluation of the Toxicity and Toxicokinetics of Cereulide from an Emetic Bacillus cereus Strain of Milk Origin. Toxins (Basel), 8(6), 156. https://doi.org/10.3390/toxins8060156

Dierick, K., Coillie, E. V., Swiecicka, I., Meyfroidt, G., Devlieger, H., Meulemans, A., Hoedemaekers, G., Fourie, L., Heyndrickx, M., \& Mahillon, J. (2005). Fatal family outbreak of Bacillus cereus associated food poisoning. Journal of Clinical Microbiology, 43(8), 4277-4279. https://doi.org/10.1128/JCM.43.8.4277-4279.2005

Della, Gaspera, A. D., Caffer, M. I., Panagópulo, M., Viñas, M. R., Barrios, H. A., Viora, S. S., \& Anselmo, R. J. (2015). Shigelosis outbreak in the city of Lujan, Argentina. Revista Argentina de Microbiologia, 47(2), 
112-7. https://doi.org/10.1016/j.ram.2015.02.003.

European Commission, (2005). Commission Regulation (EC) No/2005 of 15 November (2005) on microbiological criteria for foodstuffs. (L-338), 1-26.

Federal Agency for the Safety of the Food Chain (FASFC), (2015). Sci Com 2014/21). Advice 03-2015 of the Scientific Committee on the evaluation of the microbiological stability of rice cakes after baking. http://www.afsca.be/comitescientifique/avis/2015/_documents/AVIS03-2015_FR_DOSSIER_2014-21_B.p df.

Finlay, W. J. J., Logan, N. A., \& Sutherland, A. D., (2002). Bacillus cereus emetic toxin production in cooked rice. Journal of Food Microbiology, 19(5), 431-439. https://doi.org/10.1006/fmic.2002.0505

ISO (2004). Microbiology of food and animal feeding stuffs--Horizontal method for the enumeration of presumptive Bacillus cereus Colony count technique at $30^{\circ} \mathrm{C}$. International Organization for Standardization.

ISO (2003). Horizontal method for the enumeration of coagulase-positive Staphylococcus aureus colony count technique. International Organization for Standardization.

ISO (2004). Microbiology of food and animal feeding stuffs. method for the detection and enumeration of Enterobacteriaceae. International Organization for Standardization.

ISO (2013). Horizontal method for the enumeration of surface counting mesophilic aerobic bacteria colony count technique at $30^{\circ} \mathrm{C}$. International Organization for Standardization.

Gutiérrez, D., Delgado, S., Vázquez-Sánchez, D., Beatriz Martínez, B., López, M., Cabo, M. L., Ana, Rodríguez, A., Juan, J., Herrera, J. J., \& García, P. (2012). Incidence of Staphylococcus aureus and Analysis of Associated Bacterial Communities on Food Industry Surfaces. Applied environment microbiology, 78(24), 8547-8554. https://doi.org/10.1128/AEM.02045-12

Häggblom, M. M., Apetroaie, C., Andersson, M. A., \& Salkinoja-Salonen, M. S. (2002). Quantitative analysis of céréulide, the emetic toxin of Bacillus cereus, produced under various conditions. American society for microbiology, 68(5), 2479-2483. https://doi.org/10.1128/AEM.68.5.2479-2483.2002

Hennekinne, J. A., Marie-Laure, De Buyser, M. L., \& Dragacci, S. (2012). Staphylococcus aureus and its food poisoning toxins: characterization and outbreak investigation. FEMS Microbiology Reviews. 36(4), 815-836. https://doi.org/10.1111/j.1574-6976.2011.00311.x

Jääskeläinen, E. L., Häggblom, M. M., Andersson, M. A., Vanne, L., \& Salkinoja-Salonen, M. S., (2003a). Potential of Bacillus cereus for producing an emetic toxin, cereulide, in bakery products: quantitative analysis by chemical and biological methods. Journal of Food Protection, 66(6), 1047-1054. https://doi.org/10.4315/0362-028X-66.6.1047

Kim, B., Bang J., Kim, H., Kim, Y., Kim, B. S., Beuchat, L. R., \& Ryu, J. H. (2014). Bacillus cereus and Bacillus thuringiensis spores in Korean rice: prevalence and toxin production as affected by production area and degree of milling. Food Microbiology, 42, 89-94. https://doi.org/10.1016/j.fm.2014.02.021

Kohn, S. (2000). Anupdate of the U.S. baking industry. Cereal Foods World, 45, 94.

Kotzekidou, P. (2013). Microbiological examination of ready-to-eat foods and ready-to-bake frozen pastries from university canteens. Food Microbiology, 34(2), 337-343. http://dx.doi.org.10.1016/j.fm.2013.01.005

Lainez, E., Vergara, F., María E., \& Bárcenas, M. E. (2008). Quality and microbial stability of partially baked bread during refrigerated storage. Journal of Food Engineering, 89(4), 414-418. https://doi.org/10.1016/j.jfoodeng.2008.05.020

Lebert, L., Baucour, P., Lebert, A., \& Daudin, J. D. (2005). Assessment of bactrerial growth on surface of meat under common processing conditions by combining biological and physical models. Journalof Food Engeneering, 68(1), 89-98. https://doi.org/10.1016/j.jfoodeng.2004.05.026

Leuschner, R. G. K., O'callaghan, M. J. A., \& Arendt, E. K. (1998). Bacilli spoilage in part-baked and rebaked Brown Soda Bread. Journal of Food Science, 63(5), 915-918. https://doi.org/10.1111/j.1365-2621.1998.tb17926.x

Martinelli, D., Fortunato, F., Tafuri, S., Cozza, V., Chironna, M., Germinario, C., Pedalino, B., \& Prato, R. (2013). Lessons learnt from a birthday party: a Bacillus cereus outbreak, Bari, Italy, January 2012. Ann Ist Super Sanità, 49(4), 391-394. https://doi.org/10.4415/ANN_13_04_12. 
Naranjo, M., Denayer, S., Botteldoorn, N., Delbrassinne, L., Veys, J., Waegenaere, J., Sirtaine, N., Driesen, R. B., Sipido, K. R., Mahillon, J., \& Dierick, K. (2011). Sudden death of a young adult associated with Bacillus cereus food poisoning. Journal of Clinical Microbiology, 49(12), 4379-4381. https://doi.org/10.1128/JCM.05129-11

Notermans, S., \& Batt, C. A. (1998). A risk assessment approach for food-borned Bacillus cereus and its toxins. Journal of Applied. Microbiology. Symp. Suppl, 84(51), 515-615. https://doi.org/10.1046/j.1365-2672.1998.0840s151S.x

Novac, J. S., Sapers, G. M., Juneja, V. K. Microbial safety of minimally prossessed foods. CRC PRESS, ISBN 1-58716-041-2.

Osimani, A., Milanović, V., Taccari, M., Cardinali, F., Pasquini, M., Aquilanti, L., \& Clementi, F. (2016). The occurrence of spoilage yeasts in cream-filled bakery products. Journal of the Science of Food and Agriculture. https://doi.org/10.1002/jsfa.7982

Perez-Rodriguez, Valero, F. A., Todd, E. C. D., Carrasco, E., Garci'a-Gimeno, R. M., \& Zurera, G. (2007). Modeling transfer of Escherichia coli O157:H7 and Staphylococcus aureus during slicing of a cooked meat product. Meat Science, 76, 692-699. https://doi.org/10.1016/j.meatsci.2007.02.011

Posfay-Barbe, K. M., Schrenzel, J., Frey, J., Studer, R., Korff, C., Belli, D. C. et al. (2008). Food poisoning as a cause of acute liver failure. Pediatr. Infect Dis, J., 27(9), 846-847. https://doi.org/10.1097/INF.0b013e318170f2ae.

Rajkovic, A., Uyttendaele, M., Vermeulen, A., Andjelkovic, M., Fitz-James, I., in’t Veld, P., Denon, Q., Verhe, R., \& Debevere, J. (2008). Heat resistance of Bacillus cereus emetic toxin, cereulide. Letter. Applied. Microbiology, 46(5), 536-41. https://doi.org/10.1111/j.1472-765X.2008.02350.x

Reid, D., Fanning, S., Whyte, P., Kerry, J., Lindqvist, R., Yu, Z., \& Bolton, D. (2017). The microbiology of beef carcasses and primal during chilling and commercial storage. Food microbiology, 61, 50-57. https://doi.org/10.1016/j.fm.2016.08.003

Rosenquist, H., Smidt, L., Anderson, R. S., Jensen, B. G., \& Wilcks, A. (2005). Occurrence and significance of Bacillus cereus and Bacillus thiringiensis en ready-to-eat food. FMS Microbiology. Letters, 250(1), 129-136. https://doi.org/10.1016/j.femsle.2005.06.054

Shaheen, R., Andersson, M. A., Pirhonen, T., Jääskeläinen, E. L., Svensson, B., Nguyen-the, C., \& Salkinoja-Salonen, M. S. (2009a). Bacillus cereus spores and cereulide in food-borne illness. Ph.D. Thesis. University of Helsinki, 63. http://hdl.handle.net/10138/20853

Shiota, M., Saitou, K., Mizumoto, H., Matsusaka, M., Agata, N., Nakayama, M., et al., (2010). Rapid Detoxification of Cereulide in Bacillus cereus Food Poisoning. Pediatrics, 125(4), 951-955. https://doi.org/10.1542/peds.2009-2319

Sameer, Rushdi, Organji, S. R., Abulreesh, H. H., Elbanna, K., Osman, G. E. H., \& Khider, M. (2015). Occurrence and characterization of toxigenic Bacillus cereus in food and infant feces. Asian Pacific Journal of Tropical Biomedicine, 5(7), 515-520. https://doi.org/10.1016/j.apjtb.2015.04.004

Sarrias, J. A., Valero, M., \& Salmeron, M. C., (2002). Enumeration, isolation and characterization of Bacillus cereus strains from Spanish raw rice. Food Microbiology, 19(6), 589-595. https://doi.org/10.1006/fmic.2002.0514

Scicom (Wetenschappelijk comite van het Federaal Agentschap voor de Veiligheid van de Voedselketen) (2016). Microbiologische risico-evaluatie van rijsttaarten.

Seiler, D. A. L. (1978). The microbiology of cake and its ingredients. Food Trade Review, 48(6), 339-344.

Sharifzadeh, A., Hajsharifi-Shahreza, M., Ghasemi-Dehkordi, P., (2016). Evaluation of microbial contamination and chemical qualities of cream-filled pastries in confectioneries of Chaharmahal Va Bakhtiari province (southwestern Iran). Osong public health perspect, 7(6), 346-350. https://doi.org/10.1016/j.phrp.2016.09.004

Smith, J. P., Daifas, D. P., El-Khoury, W., Koukoutsis. J., \& El-Khoury. A. (2004). Shelf Life and Safety Concerns of Bakery Products. A Review, Critical Reviews. Food Science and Nutrition, 44(1), 19-55. https://doi.org/10.1080/10408690490263774

Soares, C., Marques, M. R., Tavaria, F. K., Pereira, J. O., Malcata, F. X., \& Pintado, M. M. (2011). Biodiversity and characterization of Staphylococcus species isolated from a small manufacturing dairy plant in Portugal 
José. International journal of food microbiology, 146(2), 123-9.

https://doi.org/10.1016/j.ijfoodmicro.2011.02.008

Svensson, B., Monthan, A., Shaheen, R., Andersson, M. A., Salkinoja-Salonen, M., \& Christiansson, A. (2006). Occurrence of emetic toxin producing Bacillus cereus in the dairy production chain. International. Dairy Journal, 16(7),740-749. https://doi.org/10.1016/j.idairyj.2005.07.002

Trujillo, F. J., Yeow, P. C., \& Pham, Q. T. (2003). Moisture sorption isotherm of fresh lean beef and external beef fat. Journal of Food Engineering, 60(4), 357-366.

Ureta, M. M., Olivera, D. F., \& Salvadori, V. O. (2016). Influence of baking conditions on the quality attributes of sponge cake. Food Science and Technology International, O(0), 1-10.

Voysey, P. A., \& Legan, J. D. (2014). Confectionery Products - Cakes and Pastries. Encyclopedia of food Microbiology (second edition). 497-503.

\section{Copyrights}

Copyright for this article is retained by the author(s), with first publication rights granted to the journal.

This is an open-access article distributed under the terms and conditions of the Creative Commons Attribution license (http://creativecommons.org/licenses/by/4.0/). 